\title{
Issues in operating childcare centers in Malaysia
}

\author{
Nor Azah Abdul Aziz ${ }^{1}$, Nur Hanani Zakaria ${ }^{2}$, Emilda Hashim ${ }^{3}$, Roznim Mohamad Rasli ${ }^{4}$, Erni \\ Marlina Saari ${ }^{5}$, Mazlina Che Mustafa ${ }^{6}$, Sopia Md Yassin ${ }^{7}$ \\ 1,2,4,5Faculty of Art, Computing, and Creative Industry, Sultan Idris Education University, Tanjung Malim, Malaysia \\ ${ }^{3,6,7}$ National Childhood Development Research Center, Sultan Idris Education University, Tanjung Malim, Malaysia
}

\begin{abstract}
Article Info
Article history:

Received Sep 20, 2020

Revised Jun 4, 2021

Accepted Jul 12, 2021

\section{Keywords:}

Childcare centers

Early childhood education

Encompassing economic

Financial factors

ABSTRACT

This paper discusses the qualifications of operators of Malaysian childcare centers, namely TASKA and TADIKA, and the challenges faced by practitioners in the industry of early childhood education (PAKK). This research used both qualitative and quantitative methods involving interviews and a survey. The sample study comprised 727 respondents consisting of 282 operators of TASKA and 343 operators of TADIKA. The research used a set of questionnaires and interview guidelines. The findings of the quantitative method showed the operators of TASKA and TADIKA had a diverse range of professional and academic qualifications, while the findings of the qualitative method highlighted a wide spectrum of challenges faced by operators of centers involved in the early childhood education industry. Collectively, such findings suggest that running a childcare center is fraught with a myriad of challenges encompassing economic, logistical, social, educational, and financial factors, which have to be addressed effectively. Certainly, prospective operators must seek assistance from those who are involved in the running, monitoring, and managing of such centers, notably experienced practitioners and relevant government officers. Also, to become successful entrepreneurs in this industry, they need to develop the passion and zeal to operate such centers with great success.
\end{abstract}

This is an open access article under the CC BY-SA license.

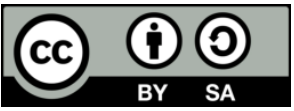

\section{Corresponding Author:}

Nor Azah Abdul Aziz

Faculty of Art, Computing and Creative Industry

Sultan Idris Education University

Tanjong Malim, Perak Darul Ridzuan 35900, Malaysia

Email: azah@fskik.upsi.edu.my

\section{INTRODUCTION}

Early childhood education is education for children at a very early age. Early childhood is a term that refers to a duration from the moment a child is borne to the time when he or she reaches eight-year-old [1]. Recently, the Deputy Minister of Women, Family, and Society Development, Hannah Yeoh, proposed several measures to improve the quality of the industry of early childhood education, which has been perceived to be of poor quality by society [2]. For example, government-run Childcare Centers (TASKA and TADIKA) need to upgrade the level of their services to remain competitive in the childcare industry [3]-[5]. Premised in this context, this paper was prepared to highlight and discuss the credential and challenges faced by TASKA and TADIKA operators in the early childhood education industry in Malaysia based on the findings of a study carried out by the authors.

The establishment of TASKA and TADIKA in Malaysia is governed by the procedures stipulated by the Malaysian government. For example, any parties, organizations, or individuals who wish to open a TASKA and a TADIKA or who are interested in being a manager of such childcare centers must attend Basic 
Early Childhood Course (Kursus Asas Awal Kanak-Kanak or KAAK) [6], [7]. In fact, the Malaysian government had passed two acts to ensure every Malaysian child will be provided with early childhood education, namely the Children Act 2001 and Act 611, with the latter being revised in 2011 to be in line with the United Nations' CRC, which was signed by Malaysia in 1995. Specifically, the Act 611 stipulates that it is the inalienable rights of children to receive a quality education, in addition to having their parents or guardians or the nation to protect them from poverty, abuses, neglects, and exploitations, and being given the rights to communicate [8]-[11].

Under Section 2, Act 308, childcare centers are defined as any premises that take in four or more children under the age of four to be taken care of with payment. In this regard, registered childcare centers are those premises that have been registered under Section 7. More specifically, under the rules and regulations prescribed in Section 6(1), no one is allowed to run or engage in the management of an unregistered childcare center [12], [13]. In the Malaysian context, a TASKA refers to a childcare center that accepts ten or more children under the age of four. Typically, such a premise provides half-a-day or full-day services based on hourly rates. By taking in children of such an age, the Childcare Act 1984 (308) comes into force that the operator or owner of a TASKA [12]-[14].

Essentially, according to the National Pre-School Curriculum, a TADIKA is an early education center for young children between the age of four and six. It is a standard practice to place about 25 children of such ages in a classroom. The teaching and learning sessions are held five days a week, with each session lasting, not more than 3 hours [15], [16]. Further details can be referred to in the Education Act 1996 (Act 550). The setting up of TASKA and TADIKA must strictly follow the requirements and process stipulated by the appropriate guidelines, namely Garis Panduan Perancangan dan Penubuhan Taman Didikan KanakKanak (TADIKA) and Taman Asuhan Kanak-Kanak (TASKA) 2017 [17], [18]. This paper addresses the qualifications of Malaysian childcare center operators, namely TASKA and TADIKA, and the problems facing early childhood education (PAKK) industry practitioners.

\section{RESEARCH METHOD}

In this research, both qualitative and quantitative approaches were used to improve the reliability and validity of findings. The various types of validity are face validity, validity of content, validity of criteria, and validity of constructs. Test-retest reliability, inter-rater reliability, and intra-rater reliability are the various forms of reliability. Any of these criteria are tested by experts from the subject field. However, for measurement of other parameters, statistical tests are be used. The sample study comprised 727 respondents consisting of 282 operators of TASKA and 343 operators of TADIKA, with remaining being operators of both types of childcare centers [19]-[22].

A majority of the respondents were operators of privately run centers. Slightly less than a third $(27.5 \%)$ of the respondents were those who only handled the management of such centers without being involved as teachers or minders. The operators were interviewed face-to-face to elicit a first-hand account of the issues and challenges that they faced in running these centers. The research instruments used were a set of questionnaires and interview guidelines. The former was developed by focusing on the research objectives to achieve strong reliability and validity [23]-[26].

Two sessions of consultations were carried out to elicit feedback from consultants, who had been appointed to assess the research instruments such that they would be in line with the research objectives and the problem statement of the study. After the first session, initial drafts of the research instruments were developed, reviewed, and refined through discussions among the researchers such that they would be able to address all the questions of the questionnaires. Subsequently, the research instruments were validated by a panel of experts. The second session was performed to present the preliminary findings to a consultant who was engaged to ensure such findings were in line with the research objectives and problem statement of the study. The consultants and experts in this study were academicians and officers working in several relevant agencies and institutions, such as UPSI, JKM, JPNIN, KEMAS, YPKT, PPBM, and KPM, who had been involved in the early childhood education industry [27]-[30].

\section{RESULTS AND DISCUSSION}

This section is divided into two main subsections to provide detailed accounts of the quantitative and qualitative findings. 


\subsection{Quantitative findings}

The quantitative findings of this study, revealed that the operators, teachers, and minders hold two types of early childhood education (ECE) qualifications, namely professional qualifications and academic qualifications, the details of which are presented in the following subsections [31].

\subsubsection{The professional ECE qualifications among TASKA operators}

For public childcare centers, slightly more than half $(50.9 \%)$ of operators, who also doubled as minders and teachers, held relevant professional certificates. In contrast, only a small minority (14.7\%) of such operators possessed relevant diplomas. Slightly less than a third (30.3\%) of such operators, who also doubled as minders and teachers, did not have any professional qualifications, the majority of whom were operators of private childcare centers. A majority of operators had minimum professional qualifications at the certificate level. Slightly more than a third $(36.9 \%)$ of operators who did not assume the role of teacher or minder had minimum qualifications at the certificate level. Slightly more than a third $(35.4 \%)$ of operators had no professional qualifications.

\subsubsection{The professional ECE qualifications among TADIKA operators}

About a third $(36 \%)$ of operators, who also doubled as minders and teachers, had no relevant professional qualifications, the majority of whom were operators of private childcare centers. Slightly more than two- thirds (72.3) of operators who handled the administration of such centers did not have any professional qualifications. A majority of operators of pre-schools run under the Ministry of Education had professional qualifications, with 37.5\% of them having relevant Bachelor's degrees in ECE.

\subsubsection{The professional ECE qualifications among TASKA and TADIKA operators}

A majority $(43.1 \%)$ of operators who run both types of childcare centers, namely TASKA and TADIKA, held relevant professional certificates. A minority (17.6\%) of operators did not have any relevant professional qualifications. The percentage of operators with relevant diplomas who only handled the administration of such centers was $42 \%$, the majority of whom were operators of childcare centers run by KEMAS.

\subsubsection{The academic qualifications among TASKA operators who were also teachers and minders}

A majority of TASKA operators had relevant academic qualifications, the percentages of whom with certificates (MCE/SPM/O-Level), diplomas, and Bachelor's degrees were 33\%, 20.2\%, and 22.9\%, respectively. For TASKA run by Agency 1, all operators only had academic qualifications at the certificate level, namely MCE, SPM, and O-Level. For TASKA run by Agency two, all operators had relevant Bachelor's degrees.

\subsubsection{The academic qualifications among TASKA operators who were neither teachers nor minders}

A majority of TASKA operators who were neither teachers nor minders had relevant academic qualifications, the percentages of whom with diplomas and Bachelor's degrees were $43.1 \%$ and $30.8 \%$, respectively. All operators of TASKAs run by Agency two had relevant Bachelor's degrees.

\subsubsection{The academic qualifications among TADIKA operators who were teachers and minders}

Almost a third (32.9\%) of TADIKA operators who were teachers and minders had relevant diplomas, followed by those with certificates (MCE/SPM/O-Level) and Bachelor's degrees at 22.5\% and $21.4 \%$, respectively. The majority of TADIKA operators who had SPM certificates were represented by those running private TADIKAs.

\subsubsection{The academic qualifications among TADIKA operators who were neither teachers nor minders}

The majority $(43.1 \%)$ of TADIKA operators who were neither teachers nor minders were those that had relevant diplomas. Trailing behind them, at 30.8\%, were those who had relevant Bachelor's degrees. All operators of TADIKAs run by Agency two had relevant Bachelor's degrees.

\subsubsection{The academic qualifications among TASKA and TADIKA operators who were teachers and minders}

More than a third $(37.3 \%)$ of operators of TASKA and TADIKA who were teachers and minders had relevant diplomas, followed by those with certificates (MCE/SPM/ O-Level) and Bachelor's degrees at $25.5 \%$ and $23.5 \%$, respectively. A majority of such operators with relevant diplomas were represented by those running and teaching at the private centers. 
3.1.9. The academic qualifications among TASKA and TADIKA operators who were neither teachers nor minders

Almost half (48\%) of the operators of TASKA and TADIKA who were neither teachers nor minders had relevant diplomas, followed by those with Bachelor's degrees at $26 \%$. A majority of such operators with relevant diplomas were represented by those running Agency one centers.

\subsection{Qualitative findings}

The qualitative part of the study, which was carried out through face-to-face interviews, revealed several important, interesting findings, highlighting that the operators of TASKA and TADIKA were facing a number of issues and challenges. The following subsections provide detailed accounts of issues and challenges.

\subsubsection{The difficulties in setting up and running TASKA and TADIKA}

The following are the transcripts of operators' feedback relating to the difficulties in setting up and running a TASKA, and a TADIKA gathered from the interviews [31]:

"It was difficult for me as an operator of TASKA to register my childcare center as I had to deal with four agencies." (A)

"A one-stop system can certainly help facilitate the registration and renewal of licenses to my center." (B)

"The procedure to open TASKA is too complicated." (C)

"Getting approval was simply too long." (D)

"There were many instances of accidents and deaths at home-based TASKA." (E)

"Cases of abuses at unregistered TASKA or TADIKA have become front-page news." (F)

"Many of unregistered TASKA or TADIKA have not been paying any fees." (G)

"There should be a limit to the number of children that a teacher/minder can take care of." (H)

"Operators need to follow the trend in selecting the types of TADIKA." (I)

"Educational policies should apply to all schools, irrespective of their types." (J)

"Malaysia must have its own template." (K)

The responses from the operators indicate that opening new TASKAs or TADIKAs is challenging as the registration process needs to go through four agencies, the process and approval of which are complicated and long, respectively. To make matters worse, cases of abuses and deaths at home-based centers and the refusal of unregistered centers to pay fees have tarnished the reputation of registered centers. To help mitigate such issues, the operators made several recommendations. They emphasized the need to have a centralized system that could expedite the process of registration and renewal of operating licenses. They also stressed the importance to limit the number of children that a TASKA or a TADIKAs could take and operators have to follow the trends of choosing the types of such centers. Equally important, they wanted to see that educational policies must be enforced to all schools, without any exceptions, and Malaysia must have its own template of educational policies.

\subsubsection{High running cost}

The following are the transcripts of the responses given by the operators during the interviews that relate to the cost of running TASKAs and TADIKAs.

"The cost of operating a childcare center is high." (A)

"Utility bills for electricity and water are high." (B)

"Fees for our pre-school services should be comparable with those of private centers." (C)

"The government should provide some form of financial assistance through subsidies or grants." (D)

"The requirements are to fully equip the TASKA." (E)

"Relevant agencies have been neglecting the efforts put in by teachers and operators to improve student quality." (F)

"The fees charged to parents are not high because most parents are from the low-paying working class." (G)

"We could not afford to take in babies." (H)

"Incentives should be given to operators to ensure their services are well compensated." (I)

"The number of children is low." (J)

"The operators have to bear the cost of training of relevant courses." (K) 
"The government should provide some form of assistance to improve this industry, given that most operators lack funds and could no increase the fees for their services." (L)

Evidently, those operators had to grapple with several issues relating to the high cost of running TASKAs and TADIKAs, such as the high cost of electricity and water bills, workers' salaries, house rents, and low childcare service fees. The latter was inevitable because they argued that increasing the fees were not feasible as most of the children's parents were of low social-economic social status. On top of that, most operators were not able to provide baby-care services due to a lack of funds. Also, the operators lamented that their efforts to help improve student quality had been largely ignored. Given that their centers had low numbers of children and they had to bear the training cost of their personnel, their financial predicament took a turn for the worse. Collectively, such prevailing issues put a heavy strain on the operators' budgets. As such, it is imperative for the government, through its relevant agencies, to intervene by providing such operators with subsidies or grants that can certainly incentivize them to continue running such an important industry.

\subsubsection{Monitoring}

The following are the transcripts of operators' responses relating to the monitoring of their childcare centers:

"The teaching and learning carried out, and the cleanliness of centers should be monitored, as monitoring by JKM and PBT involves only registered TASKAs." (A)

"There is a lack of staff to monitor the center." (B)

"We monitor our staff and children through CCTV and report children's activities to their parents using WhatsApp group." (C)

As highlighted, the main challenges faced by the operators include a lack of monitoring of the teaching and learning process and the cleanliness of centers, and a lack of staff to monitor the children. Also, there is a need to have a more effective method of monitoring and reporting children's activities to parents.

\subsubsection{The academic qualifications and capabilities of teachers and minders}

In the interviews, the operators raised several issues and concerns about the academic qualifications and capabilities of teachers and minders, which are transcribed:

"They have the right qualifications but are not committed." (A)

"Teachers with diplomas and degrees are not necessarily better than those with SPM certificates." (B)

"The qualifications of teachers have merits and demerits which depend on teaching experiences." (C)

"Our staff tend to quit after getting qualifications." (D)

As revealed, the operators bemoaned that some of their teachers, despite having good qualifications, were not able to take care of the children effectively. They also made a point that teaching experiences were more important than academic qualifications. They also highlighted the problem of hiring good teachers. Further compounding their predicament was the tendency of their teaching staff to seek other jobs after getting relevant qualifications.

\subsubsection{Salaries of staff}

A number of issues relating to staff's salaries were revealed during the interviews. Such revelations were made clear based on their responses:

"Our staff are not paid according to their qualifications." (A)

"Salary increments are small.” (B)

"Salaries paid are not comparable with the responsibilities given." (C)

"Salaries of pre-school teachers are not the same as those of teachers of private TASKA or

TADIKA.” (D)

"Minimum salary of RM1,000.00 puts a heavy strain on operators." (E)

"Qualifications and performances should be the criteria for a minimum wage." (F) 
Based on their feedback, it is interesting to note that most of the teachers had not been paid with salaries deemed appropriate with their qualifications. Moreover, the increments of salaries were small and did not commensurate with teaching responsibility. They also pointed out the differences in salaries between government-run childcare centers and privately operated childcare centers, with the latter having better pay. They contended that the minimum wage of RM1,000.00 enforced by the government had put a heavy strain on their limited financial resources. They believed the criteria for a minimum wage should be solely based on academic qualifications and performances.

\subsubsection{Career and professional developments of teachers}

The following are the transcripts of operators' conversations relating to the development of their careers and professionalism.

"Most teaching staff lack opportunities to further develop their careers. " (A)

"For private childcare centers, only supervisors are given opportunities for career development.” (B)

"Operators are worried that staff who they have hired would quit, which would forfeit them the payments of KAP." (C)

"There is a need to identify committed staff to attend training courses." (D)

"Course fees were paid by teaching staff to relieve operators of additional financial strain."

(E)

"Teaching staff need to be given recognition to make them feel happy and appreciated in working in our centers." (F)

"Teaching staff are given incentives, such as salary increments, holidays, gifts, allowances, and others." (G)

"We have to provide a suitable career path for teaching staff based on their teaching experiences." (H)

"Teaching staff must be given opportunities to improve their skills and enrich their experiences by going through the APEL training." (I)

"Training schedules should be prepared and made available." (J)

"There is a need to provide motivational courses to teaching staff to help boost their motivation." (K)

"The management should organize and carry out in-house training periodically to help improve staff's knowledge and skills, such as training in managing fire breakouts or in an emergency." (L)

It is clear that most operators have to face a number of challenges in providing a suitable career path for their teaching staff, one of which is the need to take the latter's experiences into account. Therefore, it was hardly surprising to note that most teachers are stuck in their current positions. Another challenge that operators have to face is the possibility of their teaching staff to seek a better job or a new place after getting some professional training, the cost of which is normally borne by the former. Nonetheless, in addition to giving their teaching staff opportunities for career developments, the operators must acknowledge that their teaching staff needs to be given appropriate incentives, such as handsome salary increments and allowances and extended holidays, to make their teachers feel wanted and appreciated [31]

\subsubsection{Operators' attitudes}

Undeniably, workers' attitudes have a profound impact on the success of business entities, such as childcare centers. In the interviews, operators were asked several questions to probe their opinions on the attitudes that they believed important to the smooth running of their centers, the transcripts of which are listed:

"Courteous attitudes toward the local society, notably parents, are important." (A)

"The attitudes of operators determine the success of their childcare centers." (B)

"Operators have to strictly follow the standard operating procedures (SOPs) in dealing with parents and society." (C)

"Operators must show great tact and prudence in dealing with children with special needs, especially whose parents are still struggling to accept their children's disabilities." (D)

"Discussing with parents is challenging." (E)

"Parents should acknowledge our profession by addressing my staff with appropriate social titles - as a teacher, not a sister or auntie." (F) 
"Some parents tend to rebuke teachers without first checking the facts." (G)

"Surely, there is a need to have peer support to become successful operators of childcare centers." (H)

As enumerated, their feedback strongly suggests that operators of childcare centers must have proper attitudes toward parents and children. In particular, operators must act courteously and empathetically in dealing with parents of children with special needs [31].

\section{CONCLUSION}

This paper discusses the qualifications of operators of Malaysian childcare centers, namely TASKA and TADIKA, and the challenges faced by practitioners in the industry of early childhood education (PAKK). Over recent years, early childhood education has become an integral component in the Malaysian educational system. Thus, it is hardly surprising to see the industry of early childhood education has become more vibrant, indicating an industry that will provide many business opportunities. With more working parents, the market demand for childcare services during office hours has increased exponentially; thus, lies in the opportunities for Malaysians to open childcare centers. However, as revealed in this study, setting up and running such centers are fraught with many challenges encompassing economic, logistical, social, and financial factors, which have to be addressed effectively. Certainly, prospective operators must seek assistance from those who are involved in the running, monitoring, and managing such centers, notably experienced practitioners and relevant government officers. Also, to become successful entrepreneurs in this area, they need to develop the passion and zeal to operate such centers with great success.

To guarantee the smooth operation of their centers, they should also follow the standard operating procedures (SOPs). Admittedly, being human, in some situations involving their children, some parents may be extremely emotional or irrational.

\section{ACKNOWLEDGEMENTS}

This research study was supported by the Ministry of Finance (MOF) through the Ministry of Education (MOE) Malaysia. We thank the National Child Development Research Centre (NCDRC), Universiti Pendidikan Sultan Idris (UPSI) as the leading university in this study in collaboration with SEGi University. Funded by the Ministry of Finance through the Ministry of Education Malaysia. We thank all members of the research team who have contributed to this research. We also thank the steering committee, critical informants, teachers, parents and other stakeholders who participated in the study.

\section{REFERENCES}

[1] P. Pieng and Y. Okamoto, "Examining Preschool Children Intention Understanding and Their Conflict Resolution Strategies," Early Childhood Education Journal, vol. 48, pp. 597-606, 2020

[2] K. L. Ng, "The factors influence quality assurance level among childcare employees in Selangor," Doctoral Dissertation, Universiti Utara Malaysia, 2018

[3] L. Foong, et al., "Private sector early child care and education in Malaysia: Workforce readiness for further education," Kajian Malaysia, vol. 36, no. 1, pp. 127-154. 2018.

[4] N. F. N. Azhari, et al., "The quality of physical environment in workplace childcare centers," Procedia-Social and Behavioral Sciences, vol. 202, pp. 15-23, 2015.

[5] N. S. N. Hussin, et al., "Parental Perceptions of Childcare Service Quality: A Descriptive Analysis," International Journal of Academic Research in Business and Social Sciences, vol. 9, no. 2, pp. 1-8, 2019.

[6] M. N. Subadrah and H. Zahyah, "Do preschool teachers education affect their classroom practices and career paths?" International Journal of Education and Practice, vol. 5, no. 6, pp. 88-94, 2017.

[7] M. N. Subadrah and M. Y. Sopia, "Do Preschool Teachers Professional Qualifications Play a Role in Enhancing Their Understanding of ECCE Training?” International Journal of Asian Social Science, vol. 7, no. 9, pp. 754-763, 2017.

[8] United Nations Report, "Convention on the Rights of the Child," Committee on The Rights of The Child, Geneva, 2009. [Online]. Available: https://www.un.org/esa/socdev/unpfii//documents/CRC.GC.C.11_EN.pdf.

[9] N. A. Johan, et al., "The perception of parents toward quality of child centre in Malaysia," e-Journal of Media \& Society (e-JOMS), vol. 2, pp. 1-12, Jan. 2019.

[10] N. M. Noor and N. D. Mohd Mahudin, "Work, family and women's well-being in Malaysia," in M. Connerley, J. $\mathrm{Wu}$, eds., Handbook on well-being of working women. International Handbooks of Quality-of-Life. Netherlands: Springer Publication, Dordrecht, 2016.

[11] F. W. Yunus, "Practitioners' views on learning using children's peer interactions amongst under three year old children in Selangor, Malaysia," Asian Journal of University Education, vol. 15, no.3, pp. 54-68, 2019. 
[12] N. A. A. Aziz, N. S. Hudin, H. A. S. Muzakhir, N. H. Zakaria "Early Childhood Educators Career Pathway Opportunities in Malaysia: a Preliminary Study," International Journal of Innovation, Creativity and Change, vol. 10 , no. 8, pp. 1-7, 2019.

[13] L. Foong, K. Palanisamy, P. K. Veloo, M. Dhamotharan, and C. Loh, "Private sector early child care and education in Malaysia: Workforce readiness for further education," Kajian Malaysia, Vol. 36, No. 1, pp. 127-154, 2018.

[14] A. Fikry and H. Hassan, "Characteristics of Autism Center in Malaysia," Environment-Behaviour Proceedings Journal, vol. 1, no. 4, pp. 75-82, 2016.

[15] H. Jamaludin and B. Mohamad, "The Relationship between Service Quality and Parent Satisfaction in Early Childhood Education: A Study among Malaysian Government Servants at Putra Jaya," Global Business and Management Research, vol. 10, no. 3, pp. 486-493, 2018.

[16] S. Aziz, et al., "Knowledge and practice towards vaccination: a cross-sectional study among the parents in Sungai Petani, Kedah, Malaysia," Int. J. Sci. Eng. Res, vol. 9, no.8, pp. 1-12, 2018

[17] Kementerian Kesejahteraan Bandar, Perumahan dan Kerajaan Tempatan. Guidelines for Planning and Establishment of Kindergarten and TASKA. PLAN Malaysia (Department of Town and Country Planning) Ministry of Urban Wellbeing, Housing and Local Government, 2017. [Online]. Available: https://www.planmalaysia.gov.my/index.php/garis-panduan-perancangan/2095-17-gp027-gpp-penubuhan-tadikadan-taska-2017/file.

[18] N. M. Zakria, T. A. Ismail, W. N. Mansor, Z. Sulaiman, and T. F. Hassim, "Development of a new questionnaire to assess childcare providers' KAP regarding infant and young child feeding," Mal J Nutr., vol. 26, no. 1, pp. 51-63, 2020, doi: https://doi.org/10.31246/mjn-2019-0113.

[19] D. L. Amos, J. Mary, and B. Y. Odi, "Early Childhood Care and Education as a Gateway for Achieving Inclusive Quality Education in Nigeria," Gombe Technical Education Journal, vol. 12, no. 1, pp. 38-44, 2019. [Online]. Available: http://gotejfcetgombe.com.ng/index.php/gotej/article/view/54.

[20] S. A. S. Mahadzar and H. A. Rahman, "Knowledge, Attitude and Practice towards Hand, Foot and Mouth Disease (HFMD) Among Nursery Governesses in Klang Valley, Selangor," Mal J Med Health Sci., vol. 15, pp. 40-47, 2019. [Online]. Available: https://medic.upm.edu.my/upload/dokumen/2019121207325206_MJMHS_0293.pdf

[21] N. S. Hudin, et al., "Educators' Preparedness towards Children Safety and Health in Malaysian Preschools and Kindergartens," International Journal of Innovation, Creativity and Change, vol. 10, no. 8, pp. 187-205, 2019.

[22] S. F Hashim, et al., "Family-friendly Neighborhood in the Malaysian Perspective: A Review of Literature," International Journal of Psychosocial Rehabilitation, vol. 24, no. 2, pp. 1-7, 2020.

[23] C. N. Che Ahmad, "Development and Validation of Teacher Perception on Early Childhood Care and Education Curriculum Instrument (ECCECI)," International Journal of Academic Research in Business and Social Sciences, vol. 8, no. 1, pp. 713-724, 2018.

[24] A. F. Kharuddin, N. Azid, Z. Mustafa, K. F. Ibrahim, and D. Kharuddin, "Application of Structural Equation Modeling (SEM) in Estimating the Contributing Factors to Satisfaction of TASKA Services in East Coast Malaysia," Asian Journal of Assessment in Teaching and Learning, vol. 10, no. 1, pp. 68-76, 2020. [Online]. Available: https://ejournal.upsi.edu.my/index.php/AJATeL/article/view/2722.

[25] A. F. Kharuddin, et al., "Determining important factors of arithmetic skills among newborn babies' at Malaysian TASKA using artificial neural network," International Journal of Early Childhood Education and Care, vol. 7, pp. 33-41, 2018.

[26] S. Azmani et al., "The knowledge, attitude and confidence on first aid response among childcare providers following FAT4CP@ training in negeri sembilan, Malaysia," International Journal of Research in Pharmaceutical Sciences, vol. 10, no. 4, pp. 3600-3607, 2019.

[27] A. Oke, J. E. Butler, and C. O'Neill, "Choose Your Words Wisely: Descriptions of a Professional Early Childhood Practitioner," The Qualitative Report, vol. 24, no. 12, pp. 3047-3060, 2019.

[28] F. H. Rusly, Y. Y. A. Talib, and D. Salleh "The impact of minimum pay implementation on small businesses operating cost and sustainability: A case of service business," SHS Web of Conferences, EDP Sciences, vol. 34, 2017, pp. 1-6.

[29] M. F. Shaari, S. S. Ahmad, and I. S. Ismail, "Assessing the Quality of Overall Planning for Public Preschools at Klang Valley in Malaysia," Environment-Behaviour Proceedings Journal, vol. 5, no. 1, pp. 3-9, 2020.

[30] M. A. M. Suan, A. Ayob, and M. Rodzali, "Childcare workers' experiences of supporting exclusive breastfeeding in Kuala Muda District, Malaysia: a qualitative study," International Breastfeeding Journal, vol. 12, no. 1, pp. 2-8, 2016, doi: 10.1186/s13006-016-0095-4.

[31] N. S. Hudin, N. A. Aziz, and H. Alimon, "Development of Carers-Educators' Professionalism," Final report research code 2015-0024-106-04-2, Universiti Pendidikan Sultan Idris, 2021. 